\title{
Dampak Perubahan Modal Sosial Terhadap Perubahan Sistem Pengolahan SAMPah Di YogYakarta
}

\author{
Theresia Damai T, Kusumastuti, Isti Andini \\ Program Studi Perencanaan Wilayah dan Kota, \\ Jurusan Arsitektur, Fakultas Teknik \\ Universitas Sebelas Maret, Surakarta \\ email: trajuningsih@gmail.com
}

\begin{abstract}
Badran village is a village that used to have a reputation as thugs village and face the problem of garbage. Over time, this village managed to overcome the problem of garbage with 3R-based waste management program. This success is motivated by changes in social capital and leadership as a catalyst in the presence of co-operation. Forms of social capital that result in changes in the waste management system $R W 11$ Kampung Badran is trust, norms and networks. The third form of social capital and the existence of aspects of leadership affects the sustainability of programs aimed at managing waste in RW 11, Kampung Badran. For that we need further review of how the influence of the three components of social capital that is trust, norms and networks of the waste management system. The method used the descriptive qualitative method with the presentation of narrative technique. Based on the method applied was found that all three forms of social capital affects the implementation of waste management activities in the form of bank program garbage, composting and manufacture craft of garbage. Trust influence the process of knowledge transfer of cadres to the citizens, norms affect the implementation of programs and networks organizing effect on the acquisition of outside resources.
\end{abstract}

Keywords: social capital, trust, norms, network, $3 R$

\section{PENDAHULUAN}

Kampung Badran merupakan kampung yang dijuluki sebagai kampung preman. Kampung ini terletak di sebelah barat Stasiun Tugu Kota Yogyakarta dan berada di pinggir Sungai Winongo. Kampung ini menghadapi banyak permasalah salah satunya adalah permasalahan sampah yang mengganggu kesehatan dan kebersihan lingkungan. Kesadaran warganya yang masih rendah menyebabkan masih banyak warganya yang membuang sampah di bantaran sungai.

Sebelum tahun 2008, paradigma sistem pengelolaan sampah yang diterapkan di RW 11 Kampung Badran adalah kumpul angkut - buang tanpa melibatkan peran aktif dari warganya. Paradigma ini akhirnya berubah menjadi 3R (Reduce, Reuse, Recycle)yang bertumpu pada pengurangan timbulan dan pemanfaatan kembali sampah (Marwati, 2013:3). Inisiator dari program ini adalah tokoh setempat yakni ketua RW 11 yang baru yaitu Pak Joko Sularno.

Perubahan sistem pengelolaan sampah tersebut bersamaan dengan perubahan modal sosial yang berkembang seraya dilaksanakannya berbagai macam kegiatan pemberdayaan yang dimulai sejak tahun 2000. Hal tersebut juga didukung dengan kemunculan kepemimpinan sebagai katalis dalam pelaksanaan kegiatan kerjasama pengelolaan sampah. Modal sosial yang berkembang yakni kepercayaan (trust), norma (norms) dan jaringan (networks) (Putnam, 2000).

Berdasarkan fakta tersebut maka terdapat hubungan antara perubahan modal sosial dan perubahan sistem pengelolaan sampah. Permasalahan yang muncul dalam penelitian ini adalah bagaimana dampak perubahan modal sosial di RW 11 Kampung Badran Yogyakarta terhadap sistem pengelolaan sampah. 
Tujuan penelitian ini adalah mengetahui bagaimana dampak perubahan modal sosial terhadap sistem pengelolaan sampah di RW 11 kampung Badran Yogyakarta.

\section{METODE}

\subsection{Ruang Lingkup}

Ruang lingkup wilayah penelitian ini yaitu di RW 11 Kampung Badran, Kelurahan Bumijo, Kecamatan jetis, Kota Yogyakarta. Ruang lingkup substansi penelitian ini adalah perubahan sistem pengelolaan sampah di RW 11 Kampung Badran Yogyakarta. Perubahan sistem persampahan juga disebabkan oleh adanya perubahan modal sosial yang terdiri dari komponen meliputi kepercayaan (trust), norma sosial (norms) dan jaringan (networks) dan didukung dengan kepemimpinan yang berfungsi sebagai katalis (Covey, 2006:25).

Keberhasilan dalam perubahan modal sosial juga didukung oleh keberadaan kepemimpinan sebagai katalis dalam upaya pengelolaan sampah dan kerjasama yang terjadi di RW 11 Kampung Badran. Penelitian ini dibatasi pada periode penerapan sistem pengelolaan sampah yang terjadi pada rentang waktu 20002014. Hal ini dikarenakan pada rentang waktu tersebut terjadi perubahanperubahan yang cukup signifikan pada sistem pengelolaan sampah di RW 11 Kampung Badran Yogyakarta.

\subsection{Metode Analisis}

Teknik analisis data yang digunakan dalam penelitian ini adalah metode deskriptif kualitatif. Analisis yang dilakukan yakni analisis perubahan sistem pengelolaan sampah. Dilakukan analisis perubahan modal sosial dan peran kepemimpinan sebagai katalis. Hal ini dilakukan dengan melakukan identifikasi terhadap tahapan perubahan sistem pengelolaan sampah di RW 11 Kampung Badran Yogyakarta sesuai dengan dimensi waktu. Adapun langkah-langkah dalam analisis ini adalah :

a. Melakukan identifikasi terhadap perubahan modal sosial yang terjadi di RW 11 Kampung Badran Yogyakarta. b. Melakukan identifikasi terhadap perubahan sistem pengelolaan sampah yang terjadi di RW 11 Kampung Badran Yogyakarta.

c. Melakukan analisis secara paralel untuk mengidentifikasi dampak perubahan modal sosial terhadap sistem pengelolaan sampah di RW 11 Kampung Badran Yogyakarta.

\section{HASIL DAN PEMBAHASAN}

Hasil dari analisis dampak perubahan modal sosial terhadap sistem pengelolaan sampah yakni :

\section{A. Sesudah Tahun 2000}

Pengumpulan - Pemilahan :

a. Kepercayaan warga RW 11 kepada para kader penyuluhan sampah memberikan dampak yakni pada proses pengumpulan dan pemilahan sampah. Warga bersedia melakukan semua petunjuk yang diberikan pada saat sosialisasi terbukti tiap rumah tangga memiliki tiga macam tempat sampah untuk melakukan pemilahan. Pengadaan tempat sampah ini dilakukan dengan swadaya warga RW 11 sendiri.

b. Dampak adanya norma tanggungjawab, kesadaran lingkungan dan perasaan malu terhadap sistem pengelolaan sampah adalah dalam warga tidak pernah lupa untuk melakukan pemilahan sampah di rumahnya masing-masing.

Dengan adanya norma tanggungjawab dari para kader mereka senang terus mengingatkan warga untuk melakukan pemilahan sampah.

c. Dengan adanya kegiatan pengarahan melalui bank sampah yang diadakan seminggu sekali kader memiliki kesempatan untuk melakukan evaluasi terhadap kebersihan dan kesehatan lingkungan warga RW 11 Kampung Badran.

Pengolahan - Penyetoran :

a. Kepercayaan ketua RW kepada kader-kader dengan mengarahkan kader-kader untuk ikut serta dalam studi banding pengelolaan sampah memberikan dampak positif bagi sistem pengelolaan sampah yakni 
dalam pengorganisasian pengelolaan sampah kering / dedaunan di taman bantaran sungai. Dibentuk kelompok pengolahan sampah dedaunan kering yang bertugas membersihkan dedaunan dan mengolahnya setiap seminggu sekali.

b. Dengan adanya norma tanggungjawab dalam penyampaian informasi hasil dari studi banding maka dampaknya terhadap sistem pengelolaan sampah adalah dibentuknya kelompok pengelolaan sampah menjadi kerajinan. Pengelolaan sampah menjadi kerajinan ini mendatangkan penghasilan tambahan bagi warga RW 11.

c. Dengan adanya jejaring dengan komunitas yang lebih berhasil maka berdampak pada pengolahan sampah. Pengolahan sampah menggunakan basis komunitas dan dapat mempelajari pemasaran hasil dari hasil pengelolaan sampah.

\section{KESIMPULAN}

Dari hasil analisa dapat dilihat bahwa ternyata variabel perubahan modal sosial kepercayaan, norma dan jejaring berdampak pada pembentukan sistem pengelolaan sampah yang berbasis komunitas. Kepercayaan berpengaruh terhadap proses transfer pengetahuan dari kader kepada warga dan berpengaruh dalam proses pendelegasian tugas pengelolaan sampah. Norma berpengaruh terhadap pelaksanaan pengorganisasian program pengelolaan sampah dan pembuatan keterampilan. Jejaring berpengaruh terhadap perolehan sumber daya dari luar seperti bantuan dari pemerintah, korporasi maupun lembaga-lembaga lainnya.

\section{REFERENSI}

Putnam, Robert D. 2000. Bowling Alone: The Collapse and Revival of American Community. New York : The Brooking Institution.

Marwati, Siti. 2013. Penelitian Pengelolaan Sampah Mandiri Berbasis Masyarakat. Jurusan Pendidikan Kimia FMIPA UNY.

Covey, Stephen R. 2006. The $8^{\text {th }}$ Habit : Personal Workbook. New York : Free Press. 